Proc. Estonian Acad. Sci. Biol. Ecol., 2002, 51, 3, 204-216

\title{
Land snails in Estonian forests: numbers and species richness
}

\author{
Raivo Mänd ${ }^{\mathrm{a}}$, Tiina Talvi ${ }^{\mathrm{b}}$, Annelie Ehlvest ${ }^{\mathrm{c}}$, and Piret Kiristaja ${ }^{\text {ad }}$ \\ ${ }^{a}$ Institute of Zoology and Hydrobiology, University of Tartu, Vanemuise 46, 51014 Tartu, Estonia; \\ raivo.mand@ut.ee \\ b West-Estonian Archipelago Biosphere Reserve, Lümanda, 93822 Saaremaa, Estonia; \\ talvi@viidu.oesel.ee \\ c Estonian Malacological Society, Estonian Naturalists' Society, Struve 2, 51014 Tartu, Estonia; \\ anneli@loodusmaja.park.ee \\ d Present address: Estonian Environment Information Centre, Mustamäe tee 33, 10616 Tallinn, \\ Estonia; Piret.Kiristaja@ic.envir.ee
}

Received 7 December 2001, in revised form 25 March 2002

\begin{abstract}
A drastic decline in land snail populations has been revealed in the oligotrophic areas of acidified regions of Europe. Since snail shells are an important calcium source for forest passerines, this decline causes severe reductions in forest passerine reproductive rates. In Estonia, about $40 \%$ of all woodlands consist of pine forests on poor, naturally acidic soils. It has been shown that birds breeding in such forests suffer calcium deficiency. A research project was carried out to estimate the current situation in Estonian forest land snail populations. This was the first large-scale quantitative investigation of forest snail fauna in the eastern Baltic area. Data about the abundance and species richness of snails are presented by geologically different regions and forest types of Estonia. The effect of industrial forest liming, occurring near some big oil-shale and cement works, was studied. Our data confirm that the number of snails in a substantial portion of Estonian forests is very low, and therefore birds breeding there may be vulnerable to possible increases in acidification. However, atmospheric pollution with calcareous materials in some ecologically problematic industrial regions seems to compensate for calcium deficiency for snail populations.
\end{abstract}

Key words: land snails, species diversity, forest, calcium shortage, pollution.

\section{INTRODUCTION}

A drastic decline in land snail populations was revealed at the end of the 20th century by ecologists in the oligotrophic areas of heavily acidified regions of Europe, such as The Netherlands (Graveland et al., 1994; Graveland, 1996a, b; Graveland \& Van der Wal, 1996), southern Sweden (Wäreborn, 1992; Gärdenfors et al., 1995), and Poland (Drozdowski, 1988, 1989). Simultaneously, numerous studies have shown an increase in the proportions of birds laying either abnormally thin-shelled eggs or no eggs at all in recent years (see Graveland \& Van der Wal, 1996 for 
references), and many authors have suggested that increasing atmospheric pollution may be the cause. Graveland et al. (1994) demonstrated experimentally that defective eggshells in forest passerines may be related to a decline of snail abundance in acidified soils. Molluscs need calcium for their calcareous shells, but continuing acidification and base cation leaching may result in decreased calcium content in litter and the surface soil layer (Wäreborn, 1969, 1970, 1992). Snail shells are claimed to be the main calcium source for eggshell formation in many forest bird species (Schifferli, 1973; Graveland et al., 1994). Therefore birds inhabiting acidified areas where the number of snails has decreased may have difficulties in obtaining sufficient calcium for their eggs.

According to Graveland and his colleagues (Graveland et al., 1994; Graveland \& Van der Wal, 1996), birds can compensate for the lack of snail shells by using anthropogenic calcium sources (chicken eggshells, mortar, etc.) in densely populated areas. However, calcium deficiency may cause severe reductions in forest passerine reproductive rates in less densely populated and more natural acidified areas. There is urgent need for determining the extent of calcium deficiency in different areas with variable ecological conditions (Graveland, 1996b; Graveland \& Berends, 1997; Graveland \& Drent, 1997). Unfortunately, as Wäreborn (1992) pointed out, it is difficult to estimate the real extent of a decline in land snail populations in different regions, since there is a lack of quantitative investigations to be used as background for comparisons.

Industrial acidification is not a very serious problem in Estonia (Frey, 1988; Sepp \& Asi, 1994). Instead, in some regions in northern and north-eastern Estonia even a noteworthly base cation deposition occurs due to industrial pollution (Martin et al., 1994). However, a substantial portion of our territory (about $40 \%$ of all woodlands) is covered by pine forests on poor, naturally acidic soils (Taimre, 1989), with a low density of human population. A calcium-provision experiment carried out in the populations of two forest passerines - pied flycatcher Ficedula hypoleuca and great tit Parus major - revealed that birds indeed suffered calcium deficiency in poor pine forests in south-western Estonia (Mänd et al., 1998, 2000a, b; Tilgar et al., 1999; Tilgar, 2002; Mänd \& Tilgar, in press).

In 1995-96, we carried out a research project to estimate the current state of land snail populations in Estonian forests, in order to be able to adequately measure possible changes in the future. To our knowledge, this was the first large-scale quantitative investigation of forest snail fauna in the eastern Baltic area. Here we present data about the abundance and species richness of land snails in geologically different regions and forest types of Estonia, and also describe the effect of industrial forest liming, which has occurred in some areas.

\section{MATERIAL AND METHODS}

Three most common types of forests all over Estonia were studied: (a) dry boreal pine forests, (b) fresh boreal spruce forests, and (c) fresh boreo-nemoral deciduous/mixed forests. Eight study plots in places without significant atmospheric 
pollution were selected in each forest category. Three of them were situated in West Estonian Islands (Silurian limestone bedrock, but pine forests on sand dunes), three in southern Estonia (Devonian sandstone bedrock), and two in north-east Estonia (calcareous moraine plateau and sand dunes). In selecting study plots, we preferred nature reserves or permanent environmental monitoring sites, to ensure their persistence for future re-sampling. The detailed data about the exact location of the study plots and their botanical descriptions are given in the reports of a land snail monitoring project (Veegen, 1995, 1996) deposited in the Centre of Information and Technology of the Estonian Ministry of the Environment. To investigate the effect of industrial liming on snails, one study plot in each forest category was chosen near the oil-shale industry (Ahtme, NE Estonia) and one in pine forest near cement works (Kunda, N Estonia). All these plots are subjected to high atmospheric pollution with calcium-rich dust, especially Kunda pine forest and Ahtme deciduous forest, where the herbs and leaves were covered with a visible whitish coating. In one pine forest plot in S Estonia a liming experiment with oil-shale ash was carried out in 1987. The geographic co-ordinates of all study plots are given in Table 1. More details are given in Kiristaja (2001).

Ten litter samples were collected from each study plot using $25 \times 25 \mathrm{~cm}$ square quadrats with a distance of $10 \mathrm{~m}$ from one another. Five of them were placed tightly against the nearest tree, and snails were collected also from this side of the tree trunk up to $2 \mathrm{~m}$. The samples contained herbs, lichens, mosses, and litter layer plus the top $1-2 \mathrm{~cm}$ of the mineral soil. The material was air-dried and carefully hand-sorted in laboratory conditions, using a magnifying glass. The searching time per sample was $0.5-1.5 \mathrm{~h}$, depending on the sample volume. All snails (live individuals and empty shells separately) were counted and identified, following Kerney \& Cameron (1996).

All samples were collected in dry weather during a short mid-summer period between 22 July and 8 August in 1995 (pine and deciduous/mixed forests) and 23 July and 5 August in 1996 (spruce forests). Repeated sampling in six plots showed that the abundance of snails in the same places was about $70 \%$ higher in 1996 than in 1995. Therefore, the spruce forest data of 1996 were corrected correspondingly.

The frequencies of each snail species were expressed as the number of quadrats with the species per 10 quadrats analysed in the respective group of plots (forest type, region, or site).

After the snails were extracted from the litter, all ten litter samples from each study plot were carefully mixed. The smaller sub-samples were then taken randomly out from this homogenized material for chemical analyses. Two chemical variables were measured in the laboratory: $\mathrm{pH}$ (electrometrically in fresh litter suspended in distilled water) and total calcium content (ashed and extracted with $\mathrm{HCl}$ ).

\section{RESULTS AND DISCUSSION}

The main numerical results of the study are presented in Table 1. Among forests not subjected to industrial or experimental liming, the density of land snails (both live individuals and empty shells) and species richness and diversity were all significantly (according to the Mann-Whitney U-test) the lowest in the pine forests and the highest 
in the deciduous/mixed forests. However, the species richness and diversity in the spruce forests did not differ significantly from those in the deciduous/mixed forests. No significant variance in the evenness of species distribution was found between the studied forest categories. For better illustration of the differences between forest types, abundances of live snails and Jacknife estimates of species richness are given in Figs. 1 and 2.

A significant difference between the habitats studied was also found in the live individuals/empty shells ratio: the proportion of live individuals was significantly

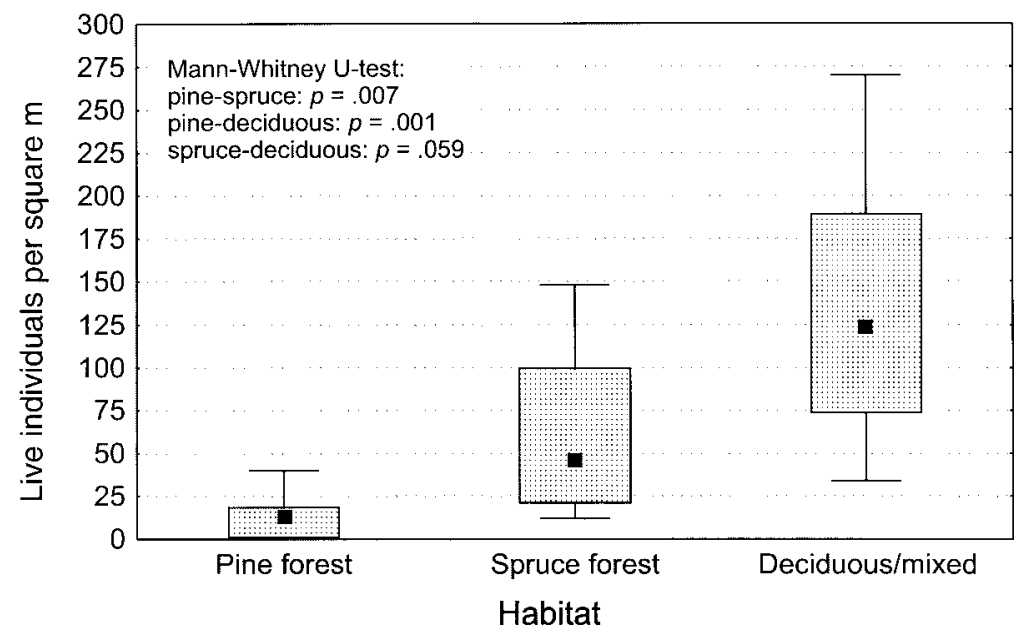

Fig. 1. Density of land snails in different forest habitats of Estonia. Median, quartiles, and minimum and maximum are given.

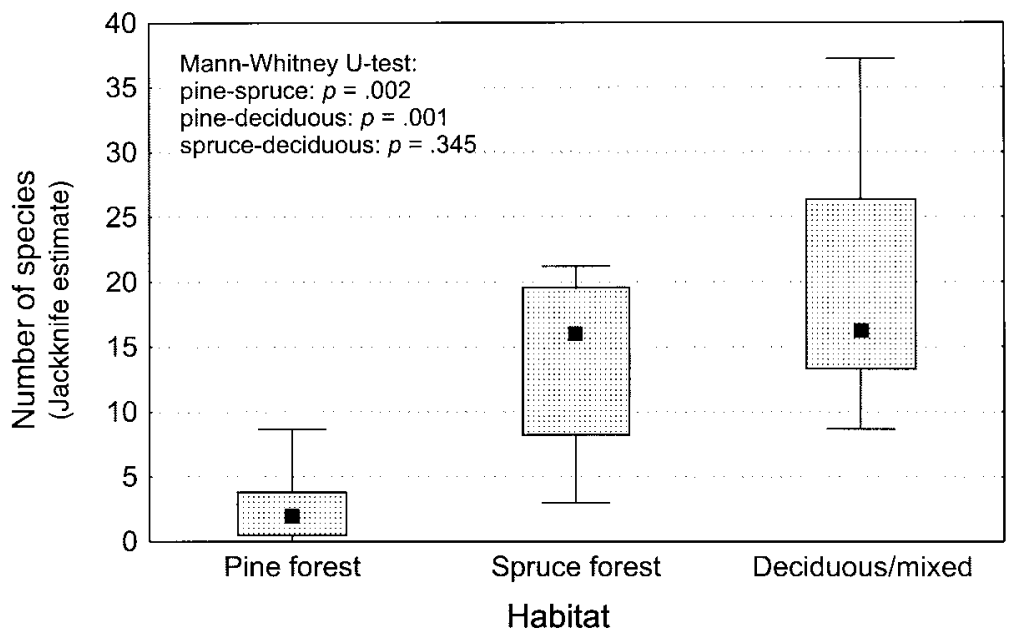

Fig. 2. Jackknife estimates of the number of land snail species in different forest habitats of Estonia. Symbols as in Fig. 1. 


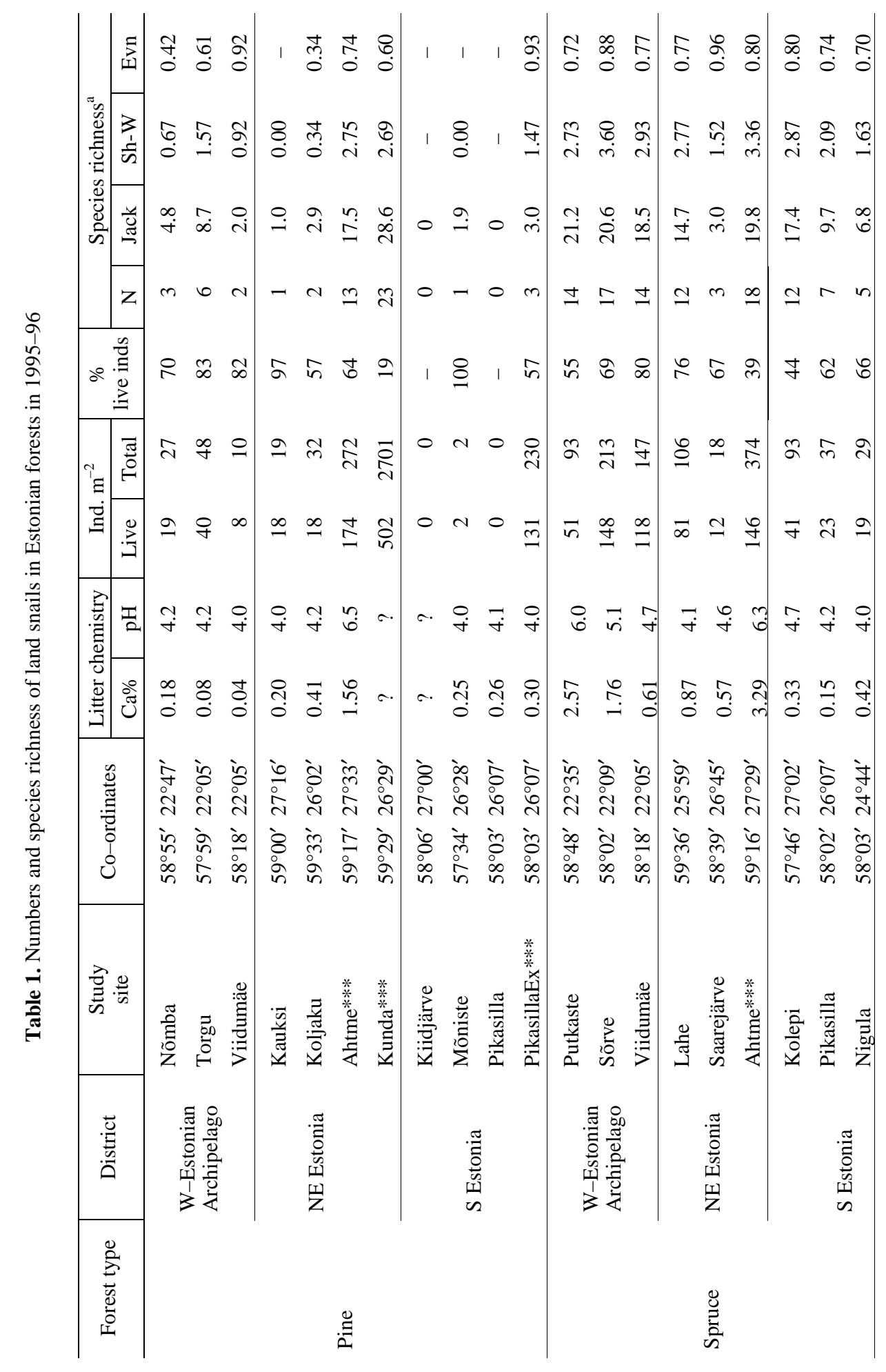




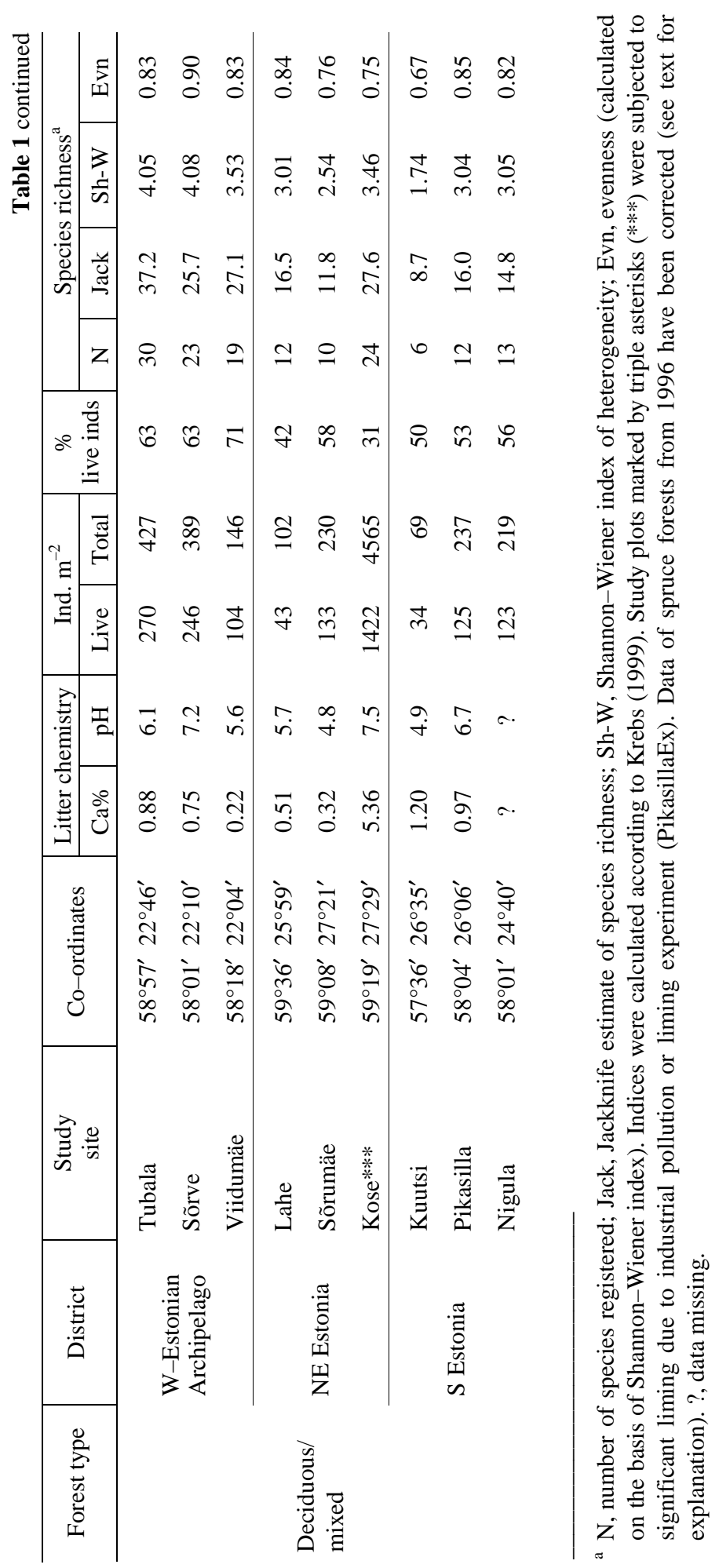


higher in the pine forests than in other habitats (Table 1; Mann-Whitney U-test; pine and spruce forests: $p=0.033$; pine and deciduous/mixed forests: $p=0.014$ ). This difference can most probably be explained by the higher corrosion rate of empty shells in more acidic environments of pine forests together with relatively higher predation by, e.g., birds and land snails. This finding is particularly important in the context of studies aimed at estimating the amount of available calcium for birds. It is not enough to present data about live individuals alone, since both live and empty shells serve as calcium sources for birds, but there is no simple relationship between these two shell categories.

Comparison of different geological regions showed that species richness is significantly higher in West Estonian Islands than in the mainland (Table 1). Also the abundance of live snails tended to be higher in the archipelago than in the mainland, although the difference was not very significant (Mann-Whitney U-test, $p=0.077$ ). The relatively high diversity of the snail fauna in the forests of West Estonian Islands is most probably related to an influence of Silurian limestone prevailing in this area. Indeed, many authors have demonstrated a clear dependence of snail abundance on soil $\mathrm{pH}, \mathrm{Ca}$ concentration, base cation concentration, and base saturation (Valovirta, 1968; Wäreborn, 1982; Gärdenfors, 1992).

An alphabetic list of 60 registered snail species together with their estimated frequencies by different regions, forest types, and artificially limed sites is given in Table 2. The frequency of Nesovitrea hammonis exceeded that of most other species approximately 5-10 times. The contrast between $N$. hammonis and other species is particularly high in dry pine forests. Altogether eight snail species were registered there, with $N$. hammonis exceeding about 10-30 times the frequency of the rest of the species (Chi-square $=17.6, \mathrm{df}=1, p<0.000)$. This is not surprising since laboratory experiments have shown that $N$. hammonis tolerate comparatively lower $\mathrm{pH}$ values and calcium levels than other common snail species (Wäreborn, 1970). However, no regional differences in the frequency of this most common forest snail were detected. Nesovitrea petronella and Aegopinella pura were the next most frequent species, inhabiting the spruce stands and the deciduous forests equally well, but, unlike $N$. hammonis, were not found in the pine forests (Table 2). No significant differences in the species composition were found between the spruce and deciduous forests, but in all pine forests the frequency of most species except $N$. hammonis was negligible.

Data from the forests subjected to significant industrial or experimental liming reveal unusually high values of snail abundance and species richness (Tables 1 and 2). This result is not surprising because of the already mentioned causal relationships between soil chemistry and snails. An artificial liming of a beech forest in southern Sweden increased the density of snails 4-40 times, depending on species and lime dose (Gärdenfors, 1992). Consequently, deposition of airborne calcium-rich materials in certain industrial regions of northern and north-eastern Estonia seems to have a clearly positive effect on local land snail populations. The data from the most polluted deciduous forest near the oil-shale industry at Ahtme (Kose forest in Table $1=$ Ahtme decid $\mathrm{f}$ in Table 2) and a pine forest near Kunda cement works show the highest values of snail density, many times exceeding the registered densities in the richest "clean" forests in Estonia (Table 1). However, it is noteworthy that the 


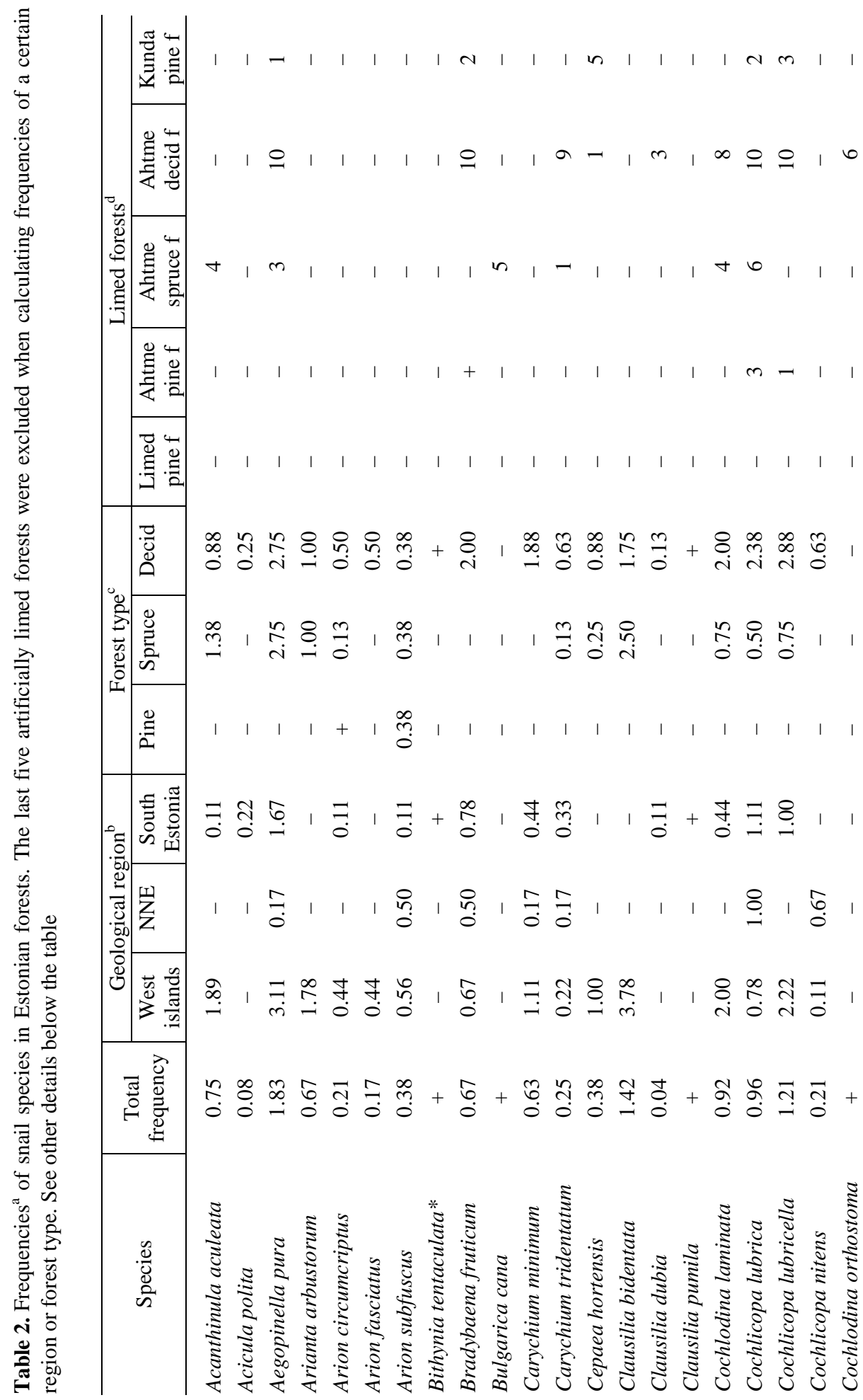




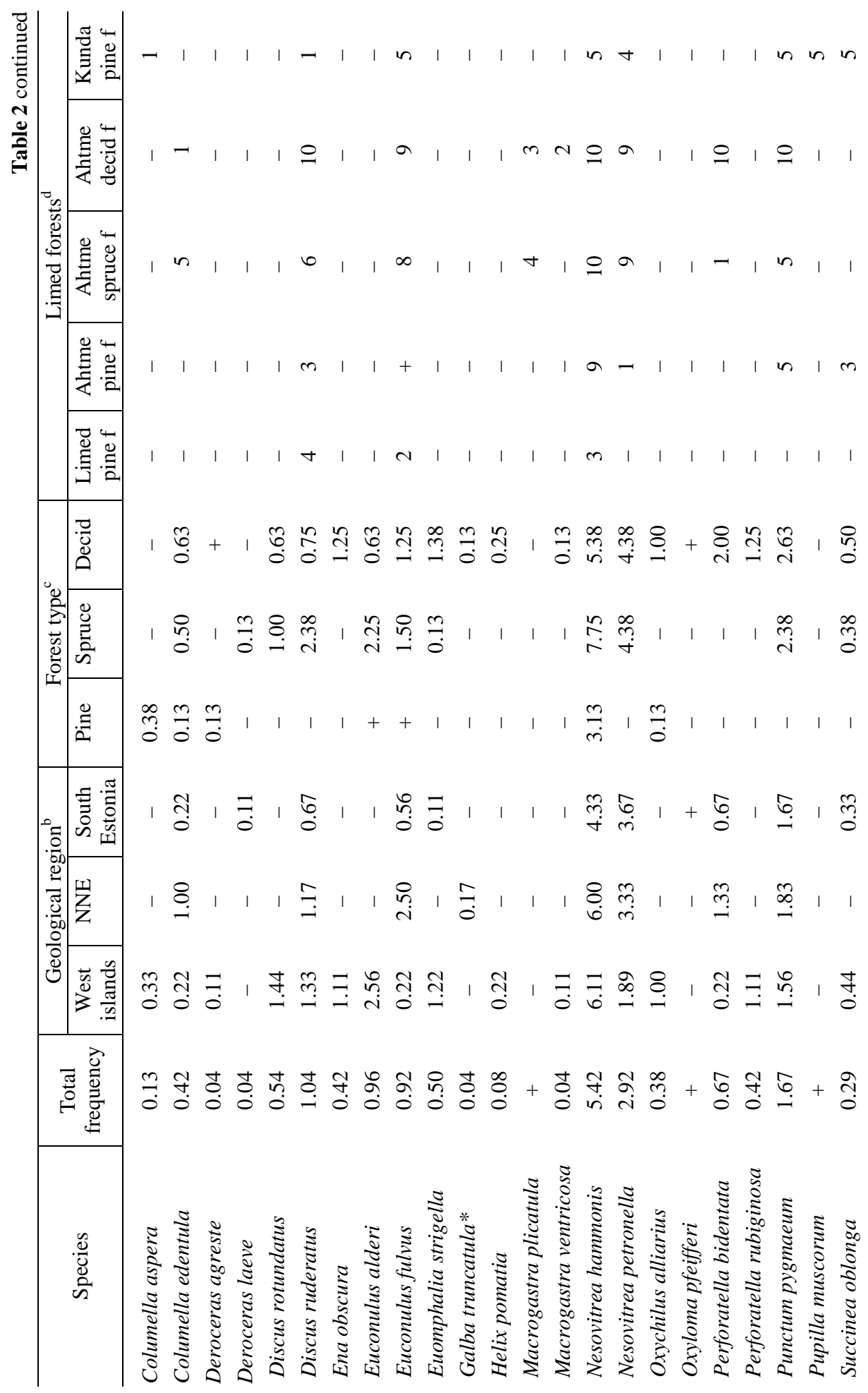




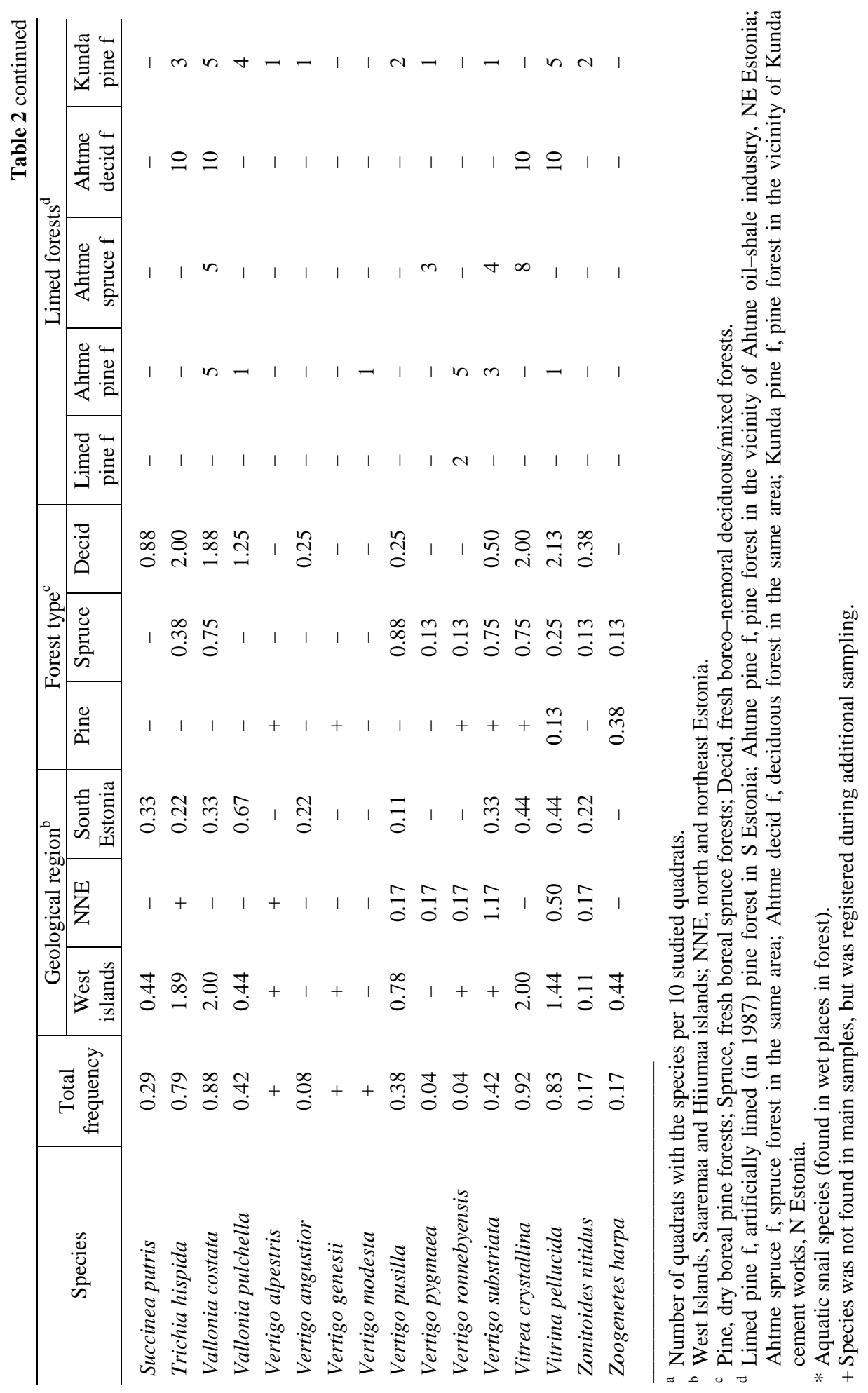


species richness in these plots did not exceed the value in the richest unpolluted study plot in the western archipelago, Tubala deciduous forest (Hiiumaa Island). A related finding was that despite the high density of snails in Pikasilla pine forest, where an experimental liming had been carried out in 1987 (PikasillaEx in Table $1=$ Limed pine $\mathrm{f}$ in Table 2 ), the number of species was still very low there. Thus an increase in snail species richness due to artificial liming seems to be a comparatively timeconsuming process, depending on the original richness of the surrounding natural biotopes, while the number of individuals (and consequently the available calcium source for forest birds) increases quite rapidly. In another study, the formation of the land snail fauna was investigated in an afforested oil-shale mining area in NE Estonia (Mänd et al., 2001). It was found that the number of species increased only three times, while the density of individuals increased more than ten times 13-23 years after planting young trees. Thus, artificial liming of naturally nutrient-poor forests does not help much to enrich the species composition of land snail community, but can sufficiently improve calcium availability for birds breeding in those forests.

Comparing our results with those of a study carried out in The Netherlands (Graveland et al., 1994; Graveland \& Van der Wal, 1996; Mänd et al., 2000b), one can see that the density and species richness of snails in pine forests of NE Estonia and the West-Estonian Archipelago is close to that in the oligotrophic forests of The Netherlands in 1970, before a drastic decline. In extensive oligotrophic pine forests on S Estonian sandstone bedrock, the number of snails is extremely low and comparable to that of poor forests in The Netherlands in the 1990s, when laying abnormalities of forest birds were already common. These data indicate that calcium deficiency may well be among ecological factors limiting the reproductive performance of passerines in naturally nutrient-poor forests in the eastern Baltic area. A long-term calcium-providing experiment, carried out in SW Estonia (Mänd et al., 1998, 2000a, b; Tilgar et al., 1999; Tilgar, 2002; Mänd \& Tilgar, 2002), supports this conclusion.

The number of snails in Estonian boreal spruce forests and boreo-nemoral deciduous/mixed forests seems to be high enough to provide birds with the necessary calcium during laying time. However, birds breeding in dry boreal pine forests, which constitute about $40 \%$ of all Estonian woodlands, may be vulnerable to possible increases in acidification. It may sound a little paradoxical, but industrial pollution with airborne calcareous materials in some ecologically problematic industrial regions seems to be able to compensate for natural calcium deficiency as well as to buffer possible negative trends.

\section{ACKNOWLEDGEMENTS}

We are grateful to Endla Asi and late Ragnar Sepp for all-round help. Mari Ivask provided valuable comments on the results. Two anonymous referees greatly improved a former version of the manuscript. The study was partly supported by the Estonian Science Foundation (grant No. 1631) and the Estonian national ecological monitoring programme. 


\section{REFERENCES}

Drozdowski, A. 1988. Untersuchungen über Veränderungen der Malacofauna des Eibenreservats Wierzchals (Pomorze, VR Polen). Malacol. Abh. (Dres.), 13, 39-48.

Drozdowski, A. 1989. Untersuchungen über Veränderungen der Malacofauna der Plutowo-Schlucht (Region Chelmno, Wojewodschaft Torun, Polen). Malacol. Abh. (Dres.), 14, 53-60.

Frey, T. 1988. Happevihmad Eestis. Eesti Loodus, Nos. 1-8, 10-12.

Graveland, J. 1996a. Avian eggshell formation in calcium-rich and calcium-poor habitats: importance of snail shells and anthropogenic calcium sources. Can. J. Zool., 74, 1035-1044.

Graveland, J. 1996b. Eggshell defects in forest passerines caused by decline of snail abundance on acidified soils. Vogelwelt, 117, 67-73.

Graveland, J. \& Berends, A. E. 1997. Timing of the calcium uptake and effect of calcium deficiency on behaviour and egg-laying in captive Great Tits, Parus major. Physiol. Zool., 70, 74-84.

Graveland, J. \& Drent, R. H. 1997. Calcium availability limits breeding success of passerines on poor soils. J. Anim. Ecol., 66, 279-288.

Graveland, J. \& Van der Wal, R. 1996. Decline in snail abundance due to soil acidification causes eggshell defects in forest passerines. Oecologia, 105, 351-360.

Graveland, J., Van der Wal, R., Van Balen, J. H. \& Van Noordwijk, A. J. 1994. Poor reproduction in forest passerines from decline of snail abundance on acidified soils. Nature, 368, 446-448.

Gärdenfors, U. 1992. Effects of artificial liming on land snail populations. J. Appl. Ecol., 29, 50-54.

Gärdenfors, U., Waldén, H. W. \& Wäreborn, I. 1995. Effects of soil acidification on forest land snails. Ecol. Bull., 44, 259-270.

Kerney, M. P. \& Cameron, R. A. D. 1996. A Field Guide to the Land Snails of Britain and North-West Europe. Wm Collins Sons, Glasgow.

Kiristaja, P. 2001. Eesti metsade maismaateod: liigirikkus ja arvukus. MSc Thesis, Tartu (manuscript in the Institute of Zoology and Hydrobiology of the University of Tartu).

Krebs, C. J. 1999. Ecological Methodology. Second Edn. Addison-Welsey Educational Publishers, Menlo Park.

Mänd, R. \& Tilgar, V. 2002. Does supplementary calcium reduce the cost of reproduction in the Pied Flycatcher Ficedula hypoleuca? Ibis, in press.

Mänd, R., Tilgar, V. \& Leivits, A. 1998. Calcium deficiency as an ecological constraint for passerines in oligotrophic forests of Estonia. Biol. Conserv. Fauna, 102, 345.

Mänd, R., Tilgar, V. \& Leivits, A. 2000a. Reproductive response of Great Tits, Parus major, in a naturally base-poor forest habitat to calcium supplementation. Can. J. Zool., 78, 689-695.

Mänd, R., Tilgar, V. \& Leivits, A. 2000b. Calcium, snails, and birds: a case study. Web Ecol., 1, 63-69.

Mänd, R., Ehlvest, A. \& Kiristaja, P. 2001. Land snails in an afforested oil-shale mining area. Proc. Estonian Acad. Sci. Biol. Ecol., 50, 15-19.

Martin, J., Reed, D. \& Noble, R. 1994. Atmosfääri saaste depositsiooni gradiendi uuringud Eestis: metodoloogia, tulemused ja perspektiivid. In Kaasaegse ökoloogia probleemid: alalhoidlik areng ja looduskeskne elulaad (Frey, T., ed.), pp. 89-93. Estonian Council of Ecology, Tartu.

Schifferli, L. 1973. The effect of egg weight on the subsequent growth of nestling Great Tits Parus major. Ibis, 115, 549-558.

Sepp, R. \& Asi, E. 1994. Metsamuldade seire ülesanded ja esialgsed tulemused. In Kaasaegse ökoloogia probleemid: alalhoidlik areng ja looduskeskne elulaad (Frey, T., ed.), pp 125-128. Estonian Council of Ecology, Tartu.

Taimre, H. 1989. Metsanduse alused. Valgus, Tallinn.

Tilgar, V. 2002. Effect of calcium supplementation on reproductive performance of the Pied Flycatcher Ficedula hypoleuca and the Great Tit Parus major, breeding in northern temperate forests. Dissertationes biologicae Universitatis Tartuensis, 71. Tartu University Press, Tartu. 
Tilgar, V., Mänd, R. \& Leivits, A. 1999. Effect of calcium availability and habitat quality on reproduction in Pied Flycatcher Ficedula hypoleuca and Great Tit Parus major. J. Avian Biol., 30, 383-391.

Valovirta, I. 1968. Land molluscs in relation to acidity on hyperite hills in central Finland. Ann. Zool. Fenn., 5, 245-253.

Veegen, A. 1995. Seireprogrammi "Maismaalimused" 1995. aasta aruanne. Estonian Ministry of Environment (manuscript in the Centre of Information and Technology of the Estonian Ministry of Environment, Tallinn).

Veegen, A. 1996. Seireprogrammi "Maismaalimused" 1996. aasta aruanne. Estonian Ministry of Environment (manuscript in the Centre of Information and Technology of the Estonian Ministry of Environment, Tallinn).

Wäreborn, I. 1969. Land molluscs and their environments in an oligotrophic area in southern Sweden. Oikos, 20, 461-479.

Wäreborn, I. 1970. Environmental factors influencing the distribution of land molluscs of an oligotrophic area in southern Sweden. Oikos, 21, 285-291.

Wäreborn, I. 1982. Environments and molluscs in a non-calcareous forest area in southern Sweden. Diss. Univ. of Lund.

Wäreborn, I. 1992. Changes in the land mollusc fauna and soil chemistry in an inland district in southern Sweden. Ecography, 15, 62-69.

\section{Maismaateod Eesti metsades: arvukus ja liigirikkus}

\section{Raivo Mänd, Tiina Talvi, Annelie Ehlvest ja Piret Kiristaja}

Euroopa antropogeenselt hapestunud piirkondade oligotroofsetes elupaikades on täheldatud maismaatigude asurkondade drastilist allakäiku. Kuna teokojad kujutavad endast tähtsat kaltsiumiallikat metsalindudele, siis põhjustab tigude vähenemine tõsiseid tagajärgi ka metsavärvuliste sigimisedukusele. Umbes $40 \%$ Eesti metsadest on männikud, mis kasvavad vaestel, looduslikult happelistel muldadel. Varasemates töödes on näidatud, et sellistes metsades pesitsevad linnud kannatavad samuti spetsiifilise kaltsiumivaeguse all. Eesti metsade maismaatigude populatsioonide praeguse olukorra hindamiseks korraldatud uurimisprojekt on ühtlasi esimene suuremastaabiline kvantitatiivne metsatigude fauna uuring Baltikumis. Andmed tigude arvukuse ja liigirikkuse kohta koguti erinevate geoloogiliste regioonide ja metsatüüpide kaupa. Uuriti ka põlevkivitööstuste ja tsemenditehase poolt põhjustatud atmosfäärse aluselise metsasaaste mõju tigudele. Tulemused näitavad, et tigude arvukus suures osas Eesti metsades on väga madal, mistõttu seal pesitsevad linnud võivad keskkonna hapestumise korral olla ohustatud. Samas just mõnedes ökoloogiliselt problemaatilistes piirkondades esinev keskkonna saastamine kaltsiumirikka heitmega kompenseerib sealsetes elupaikades esinevat kaltsiumidefitsiiti ja paistab seega mõjuvat tigude asurkonnale soodsalt. 